\title{
Dry Season Feeding Technologies: Assessing the Nutritional and Economic Benefits of Feeding Hay and Silage to Dairy Cattle in South-Western Uganda
}

\author{
Proscovia Renzaho Ntakyo ${ }^{1,2}$, Halid Kirunda ${ }^{1 *}$, Gershom Tugume ${ }^{1}$, Stephen Natuha ${ }^{1}$ \\ ${ }^{1}$ National Agricultural Research Organization, Mbarara ZARDI, Mbarara, Uganda \\ ${ }^{2}$ Kabale University, Kabale, Uganda \\ Email: ^halidkirunda@gmail.com
}

How to cite this paper: Ntakyo, P.R., Kirunda, H., Tugume, G. and Natuha, S. (2020) Dry Season Feeding Technologies: Assessing the Nutritional and Economic Benefits of Feeding Hay and Silage to Dairy Cattle in South-Western Uganda. Open Journal of Animal Sciences, 10, 627-648. https://doi.org/10.4236/ojas.2020.103041

Received: May 23, 2020

Accepted: July 27, 2020

Published: July 30, 2020

Copyright $\odot 2020$ by author(s) and Scientific Research Publishing Inc. This work is licensed under the Creative Commons Attribution International License (CC BY 4.0).

http://creativecommons.org/licenses/by/4.0/

\begin{abstract}
South-western Uganda annually experiences prolonged drought that results in dramatic drop in milk production of dairy cattle. This study was conducted to assess the nutritional value and economic benefits of feeding silage and hay to dairy cattle in the sub-region. The cross-sectional study covered seven districts with 105 farmers interviewed during the wet and 45 others in the dry season. Up to 88 soil samples were collected and analyzed for soil texture, soil $\mathrm{pH}$, organic matter and total Nitrogen, Phosphorus, Potassium, Calcium, Sodium and Magnesium. Likewise, 148 forage (105 fresh, 25 silage and 18 hay) tissues from 21 pasture species were collected and analyzed for nutritional values. Using a questionnaire, data on production costs and milk revenues were collected for cost-benefit analysis. Results showed that silage of Napier grass treated with molasses $(10.2 \mathrm{MJ} / \mathrm{kg})$ and hay of naturally established pastures $(10.6 \mathrm{MJ} / \mathrm{kg}$ ) had the highest metabolisable energy (ME) values, while the lowest $(8.30 \mathrm{MJ} / \mathrm{kg})$ was for star grass. Hay of star grass presented the highest level of crude protein (21.4\%) with maize (corn) showing the lowest (9.38\%). Digestibility of hay of naturally established mixed pastures was the highest (64.4\%), followed by that of silage of Napier grass treated with molasses (62.0\%), while star grass hay had the lowest (52.6\%). With exception of silage made from maize, all the other six forms of silage had a good crude protein (CP) content. Regardless of the good CP content $(\geq 9.9 \%)$, all silage untreated with additives was poor in quality since its ME was less than 9.9 MJ ME/kg and ration digestibility less than $67 \%$. Nonetheless, feeding of silage and hay increased milk yield and farm productivity with a benefit-cost ratio of 5.5 and 2.7 for silage and hay respectively.
\end{abstract}




\section{Keywords}

Benefit-Cost Ratio, Hay and Silage, Nutritive Values, Milk Production

\section{Introduction}

Livestock production is one major source of livelihoods for most households in South-western Uganda [1]. Over the past few years, farmers especially those in the dairy sub-sector have gradually shifted from traditional subsistence to market-oriented livestock farming. This is driven by a high demand for livestock products especially milk and meat in the country. Farmers therefore have transformed their herds from low producing local breeds to higher grade dairy cattle specifically crosses between the local breeds and Holstein Friesian, while a few farms rear pure Friesian breed of cattle. Consequently, farmers' demand for improved pastures and climate smart feeding technologies that can sustain milk production throughout the year has increased.

Whereas more effort has been directed at improving dairy cows through cross breeding of the indigenous Ankole Longhorn cattle especially with the Holstein Friesian exotic breed, little has been done to improve their nutrition. In a majority of farms animals depend on naturally growing pastures under open grazing or fenced pasture field with no paddocks or semi intensive grazing system (open with a few night paddocks). Due to climate change it has become common for South-western Uganda to experience drought for at least 183 days a year, and dairy farmers have increasingly experienced low productivity of cows due to adverse effects of prolonged drought. During such periods, farmers experience dramatic drop in milk production, with milk yield occasionally dropping to zero. Worse still, some cattle die out of starvation and dehydration due to lack of forage and/or water. While some farmers attempt to provide water, lack of forage in the dry season remains a big challenge. Improved nutrition, especially through better grazing management and supplementary feeding, has been identified as a major strategy of increasing productivity in dairy farming. Supported by some organizations including the National Agricultural Research Organization (NARO) and The Inclusive Dairy Enterprise (TIDE) project of SNV Netherlands Development Organization, many farmers in South-western Uganda have shown a desire to adopt fodder preservation including silage and hay making for feeding during the dry seasons.

Silage is forage, crop residue or agricultural and industrial by-product preserved by acids, either added or produced by natural fermentation. Fresh forage is harvested, or crop residues and by-products are collected and the material may be chopped or conditioned. This may be treated with additives and stored in absence of air so that anaerobic bacteria, present on the forage or added, can rapidly convert the water-soluble carbohydrates into lactic acids and to a lesser extent to acetic acid. Due to the production of these acids, the $\mathrm{pH}$ of the ensiled 
material becomes low (around 4), spoilage micro-organisms are inhibited, and the material can be preserved for as long as it remains in airtight storage. The quality of the ensiled product depends on the feeding value of the material ensiled, the harvesting and ensiling technique and on the fermentation products present: the types of acid and the amount of ammonia [2]. Comparatively, hay is dried forage, containing less than $15 \%$ water. Fresh forage is harvested and dried as quickly as possible. Drying can be done naturally (exposure to the sun on the ground aerating the forage regularly by turning it over) or artificially by active circulation of air. Hay can be made from improved grasses and/or legumes [3] [4]. The quantity and quality of hay also depend on the resting period before harvesting the pasture and occasionally excessive feed/nutritional losses in quality and quantity are made during processing. Currently, most (31.8\%) farmers make silage mainly from Napier grass with about $19.7 \%$ of them starting the use of maize in this practice [5]. Likewise, Rhodes grass (Chloris gayana) and Brachiaria (Brachiaria spp) have also been adopted [5]. Nonetheless, information on the losses of quality and quantity, the costs and benefits of alternative storage methods is still largely unknown.

A number of studies on feeding silage and hay have been done especially in countries with a developed livestock sector. For instance, a study in Texas recommends sorghum silage over corn silage [6]. The authors argue that sorghum silage offers higher economic benefits in terms of reduced costs compared to corn silage. In Cosovo, Kransniqi et al. [7] opine that although the costs of making silage and hay are high, constituting about $13 \%$ of farm costs, feeding silage and hay increases farm profits from milk. In Uganda, not much research has been done to guide farmers on production costs and the appropriate choice of grass and/or legumes to grow for silage and hay production.

Whereas some farmers have adopted the technology of silage and hay making as a means of preserving forage for dry season feeding, it is not clear if this is cost effective. Besides, there is no information to confirm if the farmers are appropriately applying the silage and hay making techniques in order to avoid losses in quality and quantity. The aim of this study therefore, was to assess the nutritional value and economic benefits of preserving fodder and feeding silage and hay to dairy cattle in the South-western Uganda. The findings of this study provide information useful in guiding dairy farmers in use of silage and hay for improved dairy productivity and profitability.

\section{Materials and Methods}

\subsection{Study Area and Sample Selection}

The study was conducted in seven districts in South-western Uganda including Mbarara, Isingiro, Kiruhura, Sheema, Bushenyi, Ntungamo and Lyantonde. These districts were purposively selected to represent the focus area of TIDE Project beneficiary farmers. Except for Bushenyi and Sheema, the other districts lie in the southern part of the cattle corridor of Uganda at an average elevation 
of 1800 metres above sea level [8], which is the South Western Agro-Ecological Zone. Although the study area received more than usual amount of rainfall during the study period, the predominant annual precipitation in this semi-arid zone is $900-1200 \mathrm{~mm}$ distributed in a bimodal pattern. Temperature ranges from $20^{\circ} \mathrm{C}-30^{\circ} \mathrm{C}$ with high temperature peaks recorded in January and July of each year. All the districts have mixed farming systems characterized by both crop and livestock production with the study farmers adopting the use of cattle manure in the pasture fields. In the area, the average live body weight of the cross-bred (Ankole Longhorn X Holstein Friesian) cows is $390 \mathrm{~kg}$ (file:///C:/Users/HP/Downloads/fulltext 7738.pdf). All farmers supported by TIDE Project (https://snv.org/project/inclusive-dairy-enterprise-tide) and Pearl Dairy Farms (https://en.wikipedia.org/wiki/Pearl Dairy Farms Limited) were recruited in the study. The farmers were categorized according to their grazing systems which include; zero grazing, open grazing, fenced farm with no paddocks, semi intensive (open with a few night paddocks) and rotational grazing (paddocks).

\subsection{Data and Sample Collection}

Data were collected in two cross-sectional surveys covering a period of six months; three months in the wet season and three months in the dry season. This was done in order to capture seasonal differences with the expectation that most farmers do preserve forage in form of silage and hay for dry season feeding. A total number of 105 farmers were interviewed during the wet season (December 2018-January 2019). Following a dry spell (30 days in April 2019) all the 45 farmers interviewed from Isingiro, Ntungamo and Mbarara districts were (during the wet season) again interviewed in May 2019 to capture data on making and feeding silage and hay, and daily milk production/yield and prices. The other districts (Kiruhura, Sheema, Bushenyi and Lyantonde) were not included in the second survey because they received unexpected rains that continued through what should have been the dry season and hence never fed silage and/or hay during the study period. Both qualitative and quantitative data were collected using a semi-structured questionnaire, which was administered to farmers through face to face interviews. Moreover, other data were recorded through observations made during farm visits and sample collection. To assess the nutritive value of fresh and preserved forage (silage and hay), samples including those of soils where the pastures are grown were collected (Table 1).

In the wet season, we collected data on forage nutritional value prior to being harvested for silage or hay making. We also collected data on silage and hay from a few farms where any of these existed during the time day of visit. Specifically, only 25 of the farms had silage while only 18 had hay (Table 1). To assess forage quality, tissue samples from grazing pasture fields and designated pasture gardens as well as composite soil samples (obtained at $0-15 \mathrm{~cm}$ depth) were collected. Variables of data collection included; the soil chemical composition, 
Table 1. Soil and forage samples tested.

\begin{tabular}{|c|c|c|c|c|}
\hline \multirow{2}{*}{ Sample type } & \multicolumn{4}{|c|}{ Number of samples } \\
\hline & Total & Fresh & Silage & Hay \\
\hline Maize (corn) & 24 & 21 & 3 & - \\
\hline Sorghum & 02 & 2 & - & - \\
\hline Pennisetum purpureum 0 (Kakamega variety) & 10 & 6 & 4 & - \\
\hline Pennisetum purpureum 1 (Napier grass 1 variety) & 10 & 6 & 4 & - \\
\hline Pennisetum purpureum 2 (Napier grass 2 variety) & 10 & 6 & 4 & - \\
\hline Pennisetum purpureum 3 (Napier grass 3 variety) & 12 & 8 & 4 & - \\
\hline Pennisetum purpureum $3+$ Brewer's Spent Grain (BSG) & 03 & - & 3 & - \\
\hline Pennisetum purpureum $3+$ Molasses & 3 & - & 3 & - \\
\hline Rhodes grass (Chloris gayana) & 23 & 11 & - & 12 \\
\hline Kikuyu grass (Pennisetum clandestinum) & 3 & 3 & - & - \\
\hline Brachiaria brizantha (Brachiaria grass) & 3 & 3 & - & - \\
\hline Brachiaria ruziziensis & 3 & 3 & - & - \\
\hline Brachiaria mulato & 6 & 3 & - & 3 \\
\hline Cynodon dactylon $=$ Star grass & 3 & 3 & - & - \\
\hline Tripsacum andersonii & 3 & 3 & - & - \\
\hline Setaria sphacelata & 3 & 3 & - & - \\
\hline Pennisetum clandestinum & 3 & & - & - \\
\hline Hyparrlenia rufa & 3 & 3 & - & - \\
\hline Silverleaf desmodium (Desmodium uncinatum) & 3 & 3 & - & - \\
\hline Greenleaf desmodium (Desmodium intortum) & 3 & 3 & - & - \\
\hline Tripsacum andersonii $=$ Guatemala grass & 3 & 3 & - & - \\
\hline Themeda triandra & 3 & 3 & - & - \\
\hline Alfalfa $=$ Medicago sativa & 3 & 3 & - & - \\
\hline Mixed natural grass & 6 & 3 & - & 3 \\
\hline Forage samples & 148 & 105 & 25 & 18 \\
\hline Soil samples & 88 & - & - & - \\
\hline
\end{tabular}

species of grass/legume used for silage and hay making, nutritive value of forage, nutritive value of silage/hay, factors affecting the cost of pasture production and silage/hay making, and amount of silage/hay fed to each cow per day. In the dry season, variables of data collection were restricted to the cost of processing and feeding of silage and hay, nutritional value of silage and hay, and returns from milk sales (and change in income).

\subsection{Sample and Data Analysis}

\subsubsection{Forage and Soil Sample Analysis}

The soil samples were air-dried in the laboratory, filtered through $2 \mathrm{~mm}$ sieve, oven dried at $75^{\circ} \mathrm{C}$ and ground. For soil texture, soil $\mathrm{pH}$, organic matter (OM) and total nitrogen $(\mathrm{N})$, Phosphorus $(\mathrm{P})$, Potassium $(\mathrm{K})$, Calcium $(\mathrm{Ca})$, Sodium 
(Na) and Magnesium $(\mathrm{Mg})$ were determined. Similarly, the plant tissues were oven dried at $70^{\circ} \mathrm{C}$, ground and digested at $330^{\circ} \mathrm{C}$ to generate samples for measuring total $\mathrm{N}, \mathrm{P}$ and $\mathrm{K}$. The analysis for plant tissues was restricted to total N, P and $\mathrm{K}$. The methods used for analysis were; hydrometer procedure of Bouyoucos (for texture), Walkley and Black method (for OM), Kjeldehal method (for total $\mathrm{N}$ ), colorimetric method (for available K), using flame photometer (for exchangeable basic cations including $\mathrm{Na}, \mathrm{K}$ and $\mathrm{Ca}$ ) and atomic absorption spectrophotometer in Melchel 1 (for Mg). All these methods are fully described by Murphy and Riley [9], Landon [10] and Okablebo et al. [11].

To determine crude protein content $(\mathrm{CP} \%)$, the percentage of nitrogen $(\mathrm{N} \%)$ in the forage sample was used. This was based on the fact that determining $\mathrm{CP} \%$ directly from forage can be misleading since some nitrogen is true (made up of amino acids), while the other is non-protein nitrogen-rumen microbes converted into protein [12]. Moran [12] recommends that the $\mathrm{CP} \%$ is better determined by multiplying N\% by 6.25 to get $\mathrm{CP} \%(\mathrm{CP} \%=\mathrm{N} \% \times 6.25)$. Further analysis on the same samples was done by estimating the proximate composition of the forage and this was carried out in accordance with the Association of Official Analytical Chemists [13] methods. The other parameters analysed based on the methods include crude fibre (CF), ash, moisture, crude oil and crude carbohydrate (nitrogen free extract), starch, sugar and oil. Besides, neutral detergent cellulase and gamannase digestibility (NCGD) was determined using the method of Dowman [14], while the metabolisable energy content (ME; expressed in $\mathrm{MJ} / \mathrm{kg} \mathrm{DM}$ ) was predicted using the NCGD and acid-hydrolysed ether extract (AHEE) values [15].

\subsubsection{Economic Evaluation of Feeding Silage and Hay to Dairy Cattle}

Since only 27 of the study farms practiced forage preservation and/or fed animals on silage or hay, a case study approach was used to perform an economic evaluation of feeding silage and hay to dairy cows. Moreover, most of the farmers did not keep proper records and would most likely bias the study results. Analysis of quantitative data was done using STATA Statistical Software to generate descriptive statistics on farm characteristics and other key variables. The costs included; inputs (seed, agrochemicals and fertilizers, labour costs for land preparation, planting, weeding, harvesting and processing), transport costs and cost of other materials used for making the silo as well as purchase of additives. Forage production and preservation costs were computed using mean prices provided by the farmers. Cost of land was not included as most farmers grew the fodder on part of the grazing land. The average farm prices were used to estimate revenue from milk. The cost-benefit analysis was done based on total production costs and milk revenues.

\section{Results and Discussion}

\subsection{Descriptive Statistics on Farm Characteristics}

The study observed variations in the descriptive statistics of the survey farms as 
shown in the summary in Table 2. A majority (90.5\%) of farmers were males, they had an average age of 51.9 years and most of them were married.

Most $(44.0 \%, 66 / 150)$ of the farmers had tertiary or high school (38\%) level of education. Up to $42.0 \%(63 / 150)$ of the farms employed managers with high school education and most $(79.3 \%, 119 / 150)$ of the farmers were mainly engaged in farming as their main occupation. Otherwise, at least each farm was also involved in crop farming, petty trade or formal employment in the public sector. The average farm herd size was 50 head of cattle, about $88.0 \%$ (132/150) of them grew pastures for preservation or cut and carry, while $44 \%$ of the farms sold animals because of fear of effects of the dry season. Although only 25 farmers had silage or hay at the time of the survey, up to $71.3 \%$ (107/150) and $55.3 \%$ of

Table 2. Descriptive statistics on characteristics of farms covered by the survey.

\begin{tabular}{|c|c|}
\hline Variable & Mean (Std. dev.) \\
\hline Age of farmer (years) & $51.9(11.6)$ \\
\hline \multicolumn{2}{|l|}{ Farmers' gender } \\
\hline Male & $90.5 \%$ \\
\hline Female & $9.5 \%$ \\
\hline Marital status; Married $=1$ otherwise $=0$ & $94.0 \%$ \\
\hline \multicolumn{2}{|l|}{ Education level of farm owner } \\
\hline Never attended school & $6.7 \%$ \\
\hline Primary level & $11.3 \%$ \\
\hline High school & $38.0 \%$ \\
\hline Tertiary institution & $44.0 \%$ \\
\hline \multicolumn{2}{|l|}{ Education level of farm manager } \\
\hline Never attended school & $9.5 \%$ \\
\hline Primary level & $31.7 \%$ \\
\hline High school & $42.9 \%$ \\
\hline Tertiary institution & $15.9 \%$ \\
\hline Main occupation of farmer; farming $=1$ otherwise $=0$ & $79.3 \%$ \\
\hline Secondary occupation of farmer; non-farm business & $20.7 \%$ \\
\hline Acreage (in acres) under fodder; Napier & 2.6 \\
\hline Maize & 3.2 \\
\hline Rhodes grass & 1.1 \\
\hline Herd size & $50(51)$ \\
\hline Average number of cows & $22(20)$ \\
\hline Farmers with a permanent water source & $85.3 \%$ \\
\hline Farmers who made and fed silage & $71.3 \%$ \\
\hline Farmers who make and feed hay & $55.3 \%$ \\
\hline Average Milk yield/cow/day (rainy season) (litres) & 9.0 \\
\hline Average Milk yield/cow/day (dry season) (litres) & 4.6 \\
\hline Farmers growing pastures & $88.7 \%$ \\
\hline Farmers who apply fertilizer & $46.0 \%$ \\
\hline
\end{tabular}

Source of data: survey conducted by the authors. 
those interviewed reported making and feeding silage and/or hay to cows, respectively. Most $(85.3 \%, 128 / 150)$ of the farms had established permanent sources of water, though for half of them water access was limited to a few paddocks.

Farms kept cattle under different grazing systems. Practices by $37.3 \%(56 / 150)$ of the farms, the semi-intensive grazing system (open grazing field with a few night paddocks) was most dominant (Figure 1) and Isingiro, Mbarara and Ntungamo districts recorded the highest number of farms (10, 8 and 7), respectively, with the practice. Zero grazing $(26.0 \%, 39 / 150)$ and fenced farm without paddocks $(13.3 \%, 20 / 150)$, which were the second and third most practiced systems were mainly observed in Sheema and Bushenyi districts since farmers in these districts live near trading centres. Open grazing (without any paddock) and rotational grazing (within numerous paddocks) were used by equal farm proportions $(12 \%, 18 / 150)$, while open grazing was mainly practiced in Isingiro district.

\subsection{Nutrient Content of the Soils}

The levels of soil parameters from various farms where pastures were grown are presented in Table 3. Results of soil analysis showed that most of the soils were moderately acidic with an average $\mathrm{pH}$ of 5.98. The average levels of soil N, SOM, $\mathrm{P}$ and $\mathrm{K}$ were $0.24 \%, 3.07 \%, 20.42 \mathrm{ppm}$ and $0.34 \mathrm{ppm}$, respectively.

\subsection{Nutritional Content of the Forage Used for Silage and Hay Making}

The nutritive values of the different fresh pasture species in pure stand are presented in Table 4. Cynodon dactylon (21.4\% CP), followed by Tripsacum

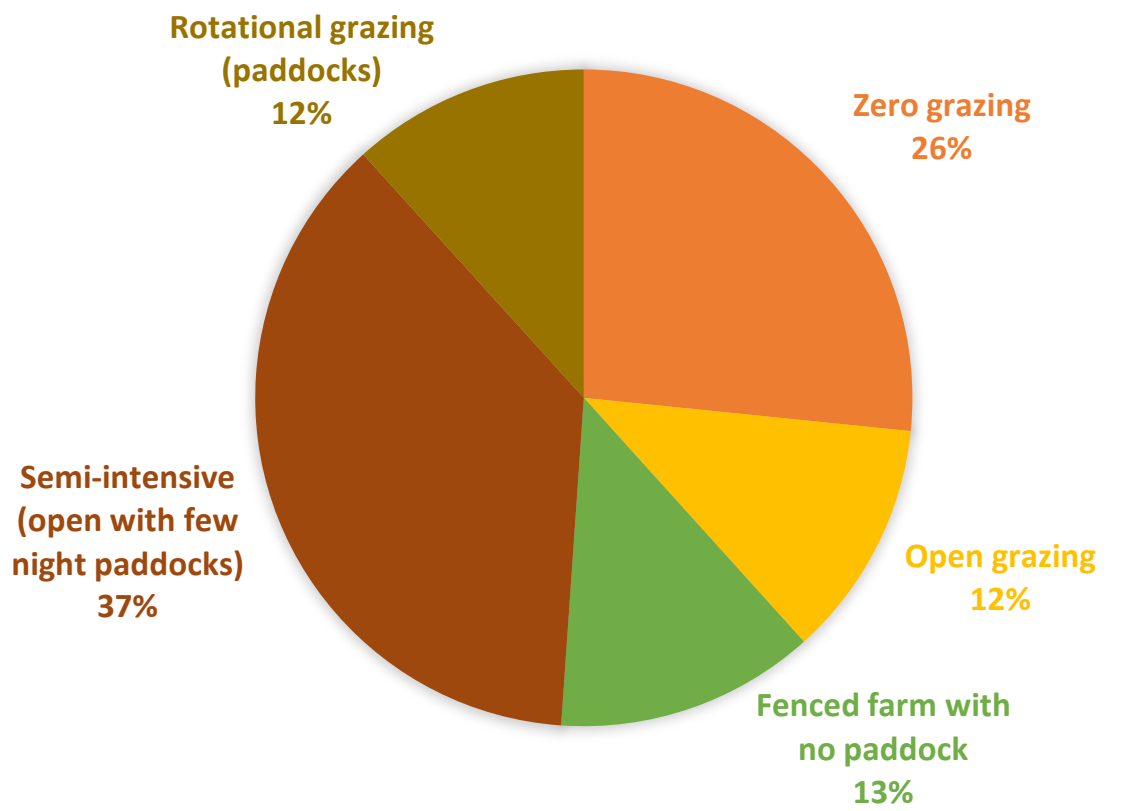

Figure 1. Grazing systems on the study farms. 
Table 3. Soil nutrient content of the study pasture fields.

\begin{tabular}{cccccc}
\hline Soil parameters & Mean & Std. Dev. & Min & Max & Range in SW Uganda \\
\hline $\mathrm{pH}$ & 5.98 & 0.93 & 0.39 & 7.04 & $4.62-8.48$ \\
$\mathrm{~N}(\%)$ & 0.24 & 0.74 & 0.07 & 6.09 & $0.05-0.38$ \\
$\mathrm{SOM}(\%)$ & 3.07 & 1.66 & 1.12 & 12.70 & $1.85-8.46$ \\
$\mathrm{P}(\mathrm{ppm})$ & 20.42 & 27.07 & 3.35 & 106 & $0.84-2140$ \\
$\mathrm{~K}(\mathrm{ppm})$ & 0.34 & 0.21 & 0.06 & 1.12 & $51.60-5030$ \\
$\mathrm{Ca}(\mathrm{ppm})$ & 2.58 & 1.83 & 0.46 & 12.4 & $220-6840$ \\
$\mathrm{Na}(\mathrm{ppm})$ & 0.10 & 0.20 & 0.01 & 1.58 & $0.60-210$ \\
Sand (\%) & 64.00 & 9.43 & 38 & 86 & $11.84-74.40$ \\
Clay (\%) & 21.97 & 7.38 & 4 & 38 & $14.32-69.60$ \\
Silt (\%) & 14.03 & 6.02 & 1 & 33 & $8.56-25.28$ \\
\hline
\end{tabular}

Key: $\mathrm{pH}=$ Alkalinity or acidity; $\mathrm{N}=$ Nitrogen; $\mathrm{SOM}=$ Soil Organic Matter; $\mathrm{P}=$ Phosphorus; $\mathrm{K}=$ Potassium; $\mathrm{Ca}=$ Calcium; $\mathrm{Na}=$ Sodium. Std. Dev. = Standard Deviation; $\mathrm{Min}=$ Minimum; Max = Maximum; $\mathrm{SW}=$ South-western.

Table 4. Nutrient composition (as is) of the pasture grasses used for making silage and hay in SW Uganda.

(a)

\begin{tabular}{|c|c|c|c|c|c|c|c|c|c|}
\hline \multirow[b]{2}{*}{ Nutrient } & \multicolumn{9}{|c|}{ Pasture species (pure stand) } \\
\hline & $\begin{array}{c}\text { Brachiaria } \\
\text { brizantha }\end{array}$ & $\begin{array}{l}\text { Brachiaria } \\
\text { ruziziensis }\end{array}$ & $\begin{array}{c}\text { Brachiaria } \\
\text { mulato }\end{array}$ & $\begin{array}{c}\text { Pennisetum } \\
\text { purpureum } \\
0\end{array}$ & $\begin{array}{c}\text { Pennisetum } \\
\text { purpureum } \\
1\end{array}$ & $\begin{array}{c}\text { Pennisetum } \\
\text { purpureum } \\
2 \\
\end{array}$ & $\begin{array}{c}\text { Pennisetum } \\
\text { purpureum } \\
3 \\
\end{array}$ & $\begin{array}{c}\text { Rhodes } \\
\text { grass }\end{array}$ & $\begin{array}{r}\text { s Chloris } \\
\text { gayana }\end{array}$ \\
\hline Energy $(\mathrm{MJ} / \mathrm{Kg})$ & 8.00 & 8.15 & 9.25 & 8.60 & 8.50 & 9.00 & 9.60 & 7.90 & 9.20 \\
\hline Protein $(\%)$ & 11.5 & 13.0 & 17.6 & 13.3 & 12.9 & 15.6 & 20.9 & 11.6 & 14.2 \\
\hline Fibre (\%) & 27.2 & 25.8 & 19.9 & 26.9 & 27.5 & 25.0 & 22.0 & 29.3 & 24.4 \\
\hline Oil (\%) & 2.80 & 2.98 & 3.52 & 3.16 & 3.20 & 3.31 & 3.65 & 2.80 & 3.74 \\
\hline Ash (\%) & 8.08 & 9.07 & 9.7 & 7.51 & 7.01 & 9.11 & 10.9 & 7.68 & 6.54 \\
\hline Starch (\%) & $<0.10$ & $<0.10$ & $<0.10$ & $<0.10$ & $<0.10$ & $<0.10$ & $<0.10$ & $<0.10$ & 0.10 \\
\hline Acid Detergent Fibre (ADF) (\%) & 37.6 & 36.5 & 30.7 & 35.3 & 36.8 & 33.5 & 30.2 & 39.6 & 32.5 \\
\hline Neutral Detergent Fibre (NDF) (\%) & 61.3 & 55.6 & 44.5 & 58.8 & 60.5 & 54.8 & 51.0 & 65.5 & 54.6 \\
\hline Sugar $(\%)$ & $<0.50$ & 0.98 & 2.17 & $<0.50$ & $<0.50$ & 0.52 & $<0.50$ & $<0.50$ & 2.03 \\
\hline Digestibility (NCGD) (\%) & 51.2 & 52.9 & 58.8 & 54.9 & 54.3 & 57.8 & 60.7 & 50.9 & 57.8 \\
\hline Dry Matter & - & 86.4 & 87.1 & - & 91.0 & 89.0 & 92.8 & 89.7 & 87.4 \\
\hline
\end{tabular}

Key: Tripsacum andersonii = Guatemala grass; Pennisetum purpureum 1 = Kakamega variety; Pennisetum purpureum-1 = NARO Napier 1 variety; Pennisetum purpureum-2 = NARO Napier 2 variety; Pennisetum purpureum-3 = NARO Napier 3 variety; $\mathrm{T}$. triandrea = Themeda triandra.

(b)

\begin{tabular}{cccccccc}
\hline & \multicolumn{5}{c}{ Pasture species (pure stand) } \\
\cline { 2 - 7 } Nutrient & $\begin{array}{c}\text { Tripsacum } \\
\text { andersonii }\end{array}$ & $\begin{array}{c}\text { Setaria } \\
\text { sphacelata }\end{array}$ & $\begin{array}{c}\text { Pennisetum } \\
\text { clandestinum }\end{array}$ & Hyparrlenia rufa & $\begin{array}{c}\text { Themeda } \\
\text { triandra }\end{array}$ & $\begin{array}{c}\text { Cynodon } \\
\text { dactylon }\end{array}$ \\
\hline Energy (MJ/Kg) & 8.60 & 8.60 & 8.2 & 8.10 & 7.20 & 8.30 \\
Protein (\%) & 16.8 & 12.3 & 14.0 & 11.8 & 9.56 & 21.4 \\
\hline
\end{tabular}




\section{Continued}

\begin{tabular}{|c|c|c|c|c|c|c|}
\hline Fibre (\%) & 25.8 & 29.3 & 24.1 & 28.9 & 31.8 & 20.6 \\
\hline Oil (\%) & 3.02 & 3.52 & 2.20 & 3.09 & 2.18 & 3.29 \\
\hline Ash (\%) & 7.93 & 9.66 & 10.8 & 7.09 & 6.86 & 8.53 \\
\hline Starch $(\%)$ & $<0.10$ & $<0.10$ & $<0.10$ & $<0.10$ & $<0.10$ & $<0.10$ \\
\hline Acid Detergent Fibre (ADF) (\%) & 36.7 & 38.7 & 34.8 & 41.4 & 42.6 & 32.1 \\
\hline Neutral Detergent Fibre (NDF) (\%) & 58.9 & 60.8 & 54.2 & 61.5 & 69.6 & 49.3 \\
\hline Sugar (\%) & $<0.50$ & 0.55 & 2.32 & $<0.50$ & $<0.50$ & 3.44 \\
\hline Digestibility (NCGD) (\%) & 55.3 & 54.0 & 54.2 & 51.9 & 46.8 & 52.6 \\
\hline Dry Matter & & 87.4 & 81.8 & 89.4 & 90.3 & 87.9 \\
\hline
\end{tabular}

Tripsacum andersonii $=$ Guatemala grass; Pennisetum clandestinum $=$ Kikuyu grass; Cynodon dactylon $=$ Star grass .

andersonii (16.8\% CP), Pennisetum clandestinum (14.0\% CP) and Setaria sphacelata $(12.3 \% \mathrm{CP})$ had the highest $\mathrm{CP}$ levels. Among the pasture grasses promoted for silage and hay making in South-western Uganda, NARO Napier 3 (Pennisetum purpureum) had 20.9\% CP, followed by Brachiaria mulato (17.9\% $\mathrm{CP}$ ) and NARO Napier 2 (Pennisetum purpureum) with $15.6 \% \mathrm{CP}$. The least CP level of $13.3 \%$ and $12.9 \%$ was observed with samples of indigenous Napier grass 0 (Pennisetum purpureum) and NARO Napier 1 (Pennisetum purpureum), respectively. With exception of NARO Napier 3 (Pennisetum purpureum) which had dry matter digestibility of $60.7 \%$, all the other grass pasture species had proportions lower than $60.0 \%$ for this variable. Comparatively, Alfalfa (24.2\%) and the naturally growing grass-legume mixed pastures (19.8\%) had the highest CP content among the pastures in either a pure legume or legume-grass mixed stand (Table 5). Furthermore, the legume pasture species (pure stand) including Alfalfa (67.4\%), Silverleaf desmodium (67.0\%) and Greenleaf desmodium (64.2\%) demonstrated the highest level of digestibility. All the other species (Table 5) had digestibility proportions of less than $60.0 \%$.

\subsection{Pasture Species Used in Silage and Hay Making}

The study observed that most $(75.7 \%, 81 / 107)$ of the farmers used Napier grass to make silage, while the rest used maize. Other pastures included Rhodes grass (Chloria gayana), Brachiaria species and Kikuyu grass (Pennisetum clandestinum) that were grown by $63.9 \%, 3.0 \%$ and $2.0 \%$, respectively, of the 83 farmers that used pastures for feeding as fresh forage (cut and carry) or hay.

\subsection{Silage and Hay Making}

Of the farms where silage was reportedly made (Table 2$), 66.4 \%(71 / 107)$ of them used Napier grass that was harvested at 75 to $150 \mathrm{~cm}$ plant height or 30 to 80 days of regrowth. In contrast, $30 \%$ of the farms harvested the forage at a stage where the plant was more than $150 \mathrm{~cm}$ plant height or more than 40 days of regrowth. About 21.3\% (32/150) of farmers interviewed grew maize particularly 
Table 5. Nutrient composition of the pasture legumes and legume-grass mixtures used in feeding dairy cattle in SW Uganda.

\begin{tabular}{ccccccc}
\hline & & Legume pasture species & & \multicolumn{2}{c}{ Pasture species (mixed stand) } \\
\cline { 2 - 7 } Nutrient & $\begin{array}{c}\text { Greenleaf } \\
\text { desmodium }\end{array}$ & Alfalfa & $\begin{array}{c}\text { Silverleaf } \\
\text { desmodium }\end{array}$ & $\begin{array}{c}\text { Grass-legume } \\
\text { mixture }\end{array}$ & $\begin{array}{c}\text { Mixed grass } \\
\text { pastures }\end{array}$ & $\begin{array}{c}\text { Chloris gayana + } \\
\text { Centrosema }\end{array}$ \\
\hline Energy (MJ/Kg) & 10.3 & 11.1 & 10.8 & 9.30 & 8.90 & 9.30 \\
Protein (\%) & 18.2 & 24.2 & 18.3 & 19.8 & 13.3 & 16.5 \\
Fibre (\%) & 22.1 & 14.5 & 19.7 & 20.6 & 26.9 & 23.5 \\
Oil (\%) & 4.57 & 5.51 & 4.98 & 3.72 & 3.32 & 3.81 \\
Ash (\%) & 5.99 & 9.22 & 7.24 & 6.48 & 9.12 & 8.28 \\
Starch (\%) & $<0.10$ & $<0.10$ & 0.79 & $<0.10$ & $<0.10$ & $<0.10$ \\
Acid Detergent Fibre (ADF) (\%) & 38.8 & 24.6 & 30.8 & 33.8 & 36.1 & 31.9 \\
Neutral Detergent Fibre (NDF) (\%) & 50.8 & 28.8 & 44.3 & 43.1 & 56.8 & 53.3 \\
Sugar (\%) & $<0.50$ & 7.21 & 0.58 & 4.22 & 1.78 & 2.25 \\
Digestibility (NCGD) (\%) & 64.2 & 67.4 & 67.0 & 58.4 & 56.9 & 88.6 \\
Dry Matter & 88.3 & 82.5 & 89.4 & 87.8 & 88.8 \\
\hline
\end{tabular}

Key: Greenleaf desmodium = Desmodium intortum; Silverleaf desmodium $=$ Desmodium uncinatum; Alfalfa $=$ Medicago sativa.

for making silage. Of the farms that used maize for silage making, 50.0\% (16/32) of them harvested maize at milk ripe stage (Milk ripe-yellowish white colour stage, much pressure in grain, content is like milk) (Figure 2). Only 15.6\% $(5 / 32)$ of the visited farms harvested maize for silage at the recommended stage; when the maize dough is ripe, dark yellow in colour, the grain is still moist and the rest of the content is rather solid. Among these farms, 56.3\% (18/32) used only maize stalk for silage, while only $23.4 \%$ included maize cobs.

Maize stalks were cut at about $25-30 \mathrm{~cm}$ stalk length. Most $(59.4 \%, 19 / 32)$ farmers did not know how to process maize stalk; they chopped it to the length of more than $0.8 \mathrm{~cm}$, including $5 \%$ of farmers that chopped it longer than $15 \mathrm{~cm}$. A majority $(64.5 \%, 69 / 107)$ of farms used pit silos to preserve silage, while a few (26.2\%) did it using polythene bags or just on the surface (9.3\%). Farms used a plastic sheet to protect silos from air entry and a heavier gauge polythene cover to protect silage from water penetration. Additionally, most $(41.1 \%, 44 / 107)$ silage making farms added molasses or maize bran (Table 6) to increase the palatability and nutritive value. Treating silage with any of the two additives was done during ensiling or feeding. A few of them added livestock microbes such as MolaPlus $^{\circledR}$ (suspensions of organic acids, lactic acid bacteria, beneficial yeast and phototropic bacteria) to improve digestibility.

Of the $55.3 \%$ (83/150) farms that reported making hay (Table 2), most $(63.9 \%, 53 / 83)$ of them used Chloris gayana. During hay making, 24.1\%, (20/83) of farms harvested forage at a stage when a few flowers/seed heads start to develop and $36.1 \%$ of them processed hay through harvesting and drying. After harvesting, grass was slowly cured. While most farmers dried grass before baling it to make hay, others $(8.4 \%)$ baled it prior to drying. The proportion $(14.5 \%$, 
Table 6. Common additives to hay and silage.

\begin{tabular}{cccc}
\hline \multicolumn{2}{c}{ Silage } & \multicolumn{2}{c}{ Hay } \\
\hline Additives & Proportion (\%) of farms & Additives & Proportion (\%) of farms \\
\hline Molasses & 70.0 & Maize bran & 41.1 \\
Microbes & 6.80 & Chopped forage legumes & 29.4 \\
Maize bran & 18.3 & Molasses & 23.5 \\
MolaPlus $^{\circledR}$ & 2.30 & Minerals salts & 5.80 \\
\hline
\end{tabular}

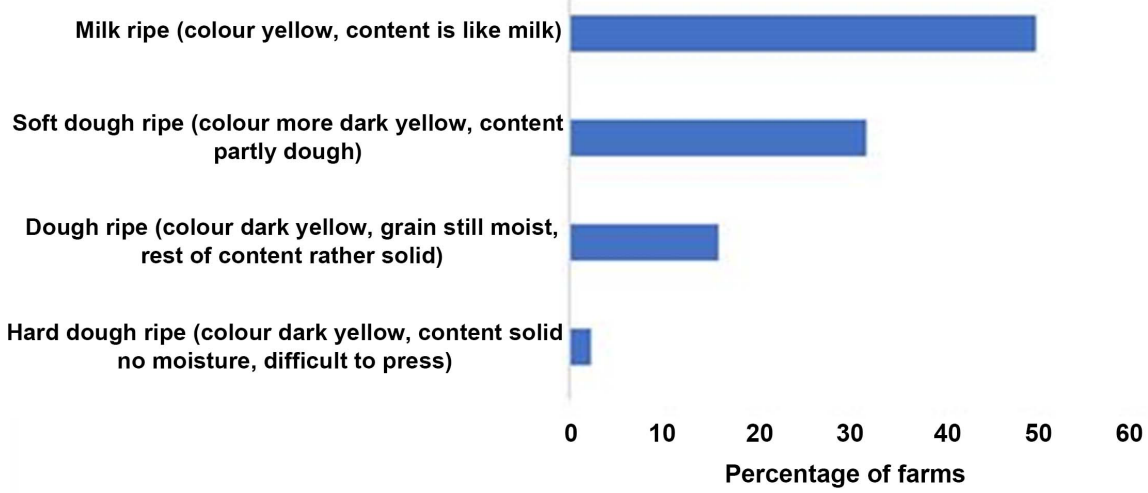

Figure 2. Stage of growth at which maize for silage was harvested.

12/83) of farmers that never made hay at the farm purchased it from elsewhere. The weight of the bales bought was approximately $15-20 \mathrm{~kg}$. Although some farmers bought hay in small quantities, others purchased it in bulk (400 - 500 bales). The cost of each bale was between Ushs 4000 and 10,000, with an average cost of Ushs 7000.

Regardless of the method used, silage compaction was poorly done and most of it appeared relatively moldy. Similar to silage, hay was fed treated/combined with maize bran, molasses and chopped forage legumes for the same reason of increasing palatability and nutritive value.

\subsection{Nutrient Content of the Preserved Forages}

Hay of naturally established pastures $(10.6 \mathrm{MJ} / \mathrm{kg})$ and silage of Napier grass treated with molasses $(10.2 \mathrm{MJ} / \mathrm{kg}$ ) had the highest ME content, while star grass showed the lowest value $(8.30 \mathrm{MJ} / \mathrm{kg}$ ) for the variable (Table 7). Comparatively, hay of star grass in pure stand presented the highest proportion of CP $(21.4 \%)$ and the lowest was for maize (9.38\%). Comparatively, the digestibility of hay of naturally growing mixed pastures was the highest (64.4\%), followed by that of silage of Napier grass treated with molasses $(62.0 \%)$ and hay from star grass (pure stand) had the lowest (52.6\%).

\subsection{Economic Analysis of Feeding Hay and Silage}

It was observed that most of the farmers were preparing silage or hay for the first 
Table 7. Nutrient composition (\% of DM) of silage and hay preserved for dairy cattle in SW Uganda.

\begin{tabular}{|c|c|c|c|c|c|c|c|}
\hline \multirow{3}{*}{ Nutrient } & \multicolumn{7}{|c|}{ Preserved pasture species (silage and hay) } \\
\hline & \multicolumn{5}{|c|}{ Silage } & \multicolumn{2}{|c|}{ Hay } \\
\hline & $\begin{array}{c}\text { Maize + } \\
\text { molasses }\end{array}$ & Maize + BSG & $\begin{array}{l}\text { Napier + } \\
\text { molasses }\end{array}$ & Napier alone & Maize alone & $\begin{array}{l}\text { Star grass } \\
\text { alone }\end{array}$ & $\begin{array}{c}\text { Mixed natural } \\
\text { pastures }\end{array}$ \\
\hline Energy (MJ/kg) & 8.70 & 9.70 & 10.2 & 9.80 & 9.60 & 8.30 & 10.6 \\
\hline Protein $(\%)$ & 10.2 & 15.6 & 14.8 & 13.7 & 9.38 & 21.4 & 16.2 \\
\hline Fibre (\%) & 28.2 & 23.3 & 23.0 & 28.1 & 19.8 & 20.6 & 20.5 \\
\hline Oil (\%) & 3.20 & 4.23 & 5.23 & 5.76 & 3.30 & 3.29 & 5.50 \\
\hline Ash (\%) & 6.11 & 5.79 & 11.6 & 12.3 & 6.04 & 8.53 & 6.83 \\
\hline Starch (\%) & $<0.10$ & $<0.10$ & $<0.10$ & $<0.10$ & 15.6 & $<0.10$ & 5.44 \\
\hline Acid Detergent Fibre (ADF) (\%) & 35.0 & 28.9 & 35.2 & 40.9 & 25.1 & 32.1 & 26.6 \\
\hline Neutral Detergent Fibre (NDF) (\%) & 63.8 & 56.1 & 47.2 & 56.2 & 48.8 & 49.3 & 50.4 \\
\hline Sugar (\%) & $<0.50$ & 0.70 & 3.50 & 1.91 & $<0.50$ & 3.44 & 1.07 \\
\hline Digestibility (NCGD) (\%) & 55.7 & 60.4 & 62.0 & 58.1 & 61.5 & 52.6 & 64.4 \\
\hline Dry Matter & 19.1 & 23.0 & 25.8 & 13.4 & 31.6 & 13.9 & 27.5 \\
\hline
\end{tabular}

Key: DM = Dry Matter; Maize (corn): Zea mays subsp. Mays; Napier grass = Pennisetum purpureum; Star grass = Cynodon dactylon; NCGD = Neutral Cellulase Gammanase Digestibility; BSG = Brewer's Spent Grain.

time and were unable to provide production costs and yield data required for economic analysis. Nonetheless, using case studies of four farms (with reasonable records) data on production costs and other inputs, feed intake, milk yields and value of milk revealed a positive margin of about UShs 725,502 (US\$207) for silage and UShs 434,562 (US\$124) for hay. Table 8 and Table 9 provide the summaries of all costs, and benefits used in the economic evaluation of feeding silage and hay, respectively. Results show that silage increased milk production from 4.6 liters when no silage or hay was fed to milking cows to 10.2 litres when fed with about $6.8 \mathrm{~kg}$ of silage per cow per day; an increase of 5.6 litres (130\%) per cow per day (Table 8). This translates into a net profit of UShs 725,502 per ton of silage fed, assuming the average farm price of UShs 1040 per litre and UShs 939,612 per ton of silage when milk was sold at the highest farm price of UShs 1300 per litre. Similarly, milk per cow per day increased by about 4.3 litres (93.4\%) from 4.6 to 8.9 litres when fed an average $7.8 \mathrm{~kg}$ of hay per day (Table 9). This translates into a net profit of UShs 434,562 and UShs 561,251 per ton of hay calculated at the average farm gate price and maximum price per litre, respectively. Since no other dairy ration was provided to lactating cows at any of the case study farms, the increase in milk production to a large extent could be directly attributed to silage/hay feeding. In both silage and hay production, labour costs contributed the highest proportion (82.0\% and 50.9\%) of total costs, respectively. The cost-benefit analysis shows positive benefit cost ratios of 5.5 and 2.7 for silage and hay respectively. 
Table 8. Costs and profitability of feeding Napier grass and maize silage to dairy cows; A case study of 4 farms.

\begin{tabular}{|c|c|c|c|c|}
\hline Variable & Mean & $\begin{array}{c}\text { Std. } \\
\text { deviation }\end{array}$ & Min & $\operatorname{Max}$ \\
\hline Cost of seed & 180,805 & 193,621 & 10,000 & 560,000 \\
\hline Cost of fertilizer & 151,750 & 236,246 & 2000 & 700,000 \\
\hline Cost of other materials & 583,650 & 416,962 & 50,000 & $1,460,000$ \\
\hline Transport costs & 421,342 & 620,158 & 20,000 & $1,800,000$ \\
\hline Cost of labour & $1,390,281$ & $1,499,088$ & 180,000 & $5,600,000$ \\
\hline Average total costs & $2,727,827$ & & & \\
\hline Quantity of silage harvested (tons) & 20.8 & 32.1 & 3.0 & 84.0 \\
\hline Cost per ton & 130,938 & & & \\
\hline Silage fed/cow/day $(\mathrm{kg})$ & 6.8 & 5.5 & 0.2 & 16 \\
\hline Dry season milk production/cow/day (no hay/silage) & 4.6 & & & \\
\hline Additional milk production/cow/day (litres) & 5.6 & & & \\
\hline Additional milk production/ton of silage & 823.5 & & & \\
\hline $\begin{array}{l}\text { Average incremental milk income } \\
\text { (changes at max price) }\end{array}$ & $\begin{array}{c}856,440 \\
(1,070,550)\end{array}$ & & & \\
\hline Milk price/litre & $\begin{array}{c}1040 \\
(1300)\end{array}$ & & & \\
\hline Benefit-cost ratio & $\begin{array}{c}5.5 \\
(7.1)\end{array}$ & & & \\
\hline Profitability & $\begin{array}{c}725,502 \\
(939,612)\end{array}$ & & & \\
\hline
\end{tabular}

Source of data: survey conducted by the authors. Notes: Labour includes; land preparation, planting, weeding and harvesting; Profit $=$ additional revenue/ton - cost/ton of silage; Additional milk due to feeding silage $=$ average production/cow in dry season feeding silage - dry season average production/cow without silage or hay; Additional milk per ton of silage $=(1000 /$ silage fed per cow per day $)$ additional milk $/$ day due to silage; Assumption: average additional milk per day is constant (for 6 months for one cow) or for 147 cows; BCR; the benefits were not discounted because the process and returns take a short time (about 6 months).

Table 9. Costs and profitability of feeding hay to dairy cows: A case study of 2 farms with Rhodes grass (Chroris gayana) hay.

\begin{tabular}{|c|c|c|c|c|}
\hline Variable & Mean & Std. deviation & Min & $\operatorname{Max}$ \\
\hline Cost of seed & 178,333 & 113,614 & 75,000 & 300,000 \\
\hline Cost of labour & 865,000 & 49,498 & 830,000 & 900,000 \\
\hline Transport costs & 5000 & & 5000 & 5000 \\
\hline Average total costs & $1,048,333$ & & 910,000 & $1,205,000$ \\
\hline Quantity of hay harvested (tons) & 6.8 & 5.3 & 3.0 & 10.5 \\
\hline Cost per ton & 155,309 & & & \\
\hline Hay fed/cow/day $(\mathrm{kg})$ & 7.8 & & & \\
\hline Dry season milk production/cow/day (no hay/silage) & 4.6 & & & \\
\hline Additional Milk production/cow/day due to hay (litres) & 4.3 & & & \\
\hline
\end{tabular}




\section{Continued}

Additional Milk production/ton of Hay (litres)

Average Changes in milk income (income based on max price of milk)

$\begin{array}{cc}\text { Milk price/litre } & 1070 \\ & (1300) \\ \text { Benefit-cost ratio } & 2.7: 1 \\ & (4.6: 1) \\ \text { Profitability } & 434,562 \\ & (561,251)\end{array}$

551.2

589,871

$(716,560)$

1070

$7: 1$

$61,251)$

Source of data: survey conducted by the authors. Notes: Labour costs includes; land preparation, planting, weeding, harvesting and processing; Profit = additional revenue/ton - cost/ton of hay; Additional milk due to feeding hay = average production/cow in dry season feeding hay - dry season average production/cow without silage or hay; Additional milk per ton of hay = (1000/hay fed per cow per day $)$ additional milk/day due to hay; Assumption: average additional milk per day is constant (for 6 months for one cow) or for 128 cows.

\section{Discussion}

Our study observed a change in the grazing system; from pastoral and open grazing systems that were previously dominant in South-western Uganda [16], to semi-intensive grazing system (open grazing field with a few night paddocks) gradually becoming dominant. This may be attributed to efforts of government and the development partners encouraging farmers to replace indigenous with improved cattle breeds. The shift by farmers to semi-intensive grazing system in the study areas corroborates results of FAO [1] which show that in South-western Uganda, up to $45 \%$ of farmers are practicing the grazing system. It is also interesting that because of on-going efforts to encourage farmers adopt rotational grazing for improved pasture utilisation, more farms than ever adopted the practice.

Results on soil $\mathrm{pH}$ of 5.98 demonstrate that most of the soils were moderately acidic, which is the acceptable $\mathrm{pH}$ for pastures such as Napier grass. The levels of soil N, OM and $\mathrm{P}$ on most farms would be regarded high, moderate or marginal if compared with results of similar studies [17]. The mean level of $\mathrm{K}$ was relatively very low $(<0.4 \mathrm{meq} / 100 \mathrm{~g}$ soil $)$ and this may negatively affect the nutritive value of pastures in the study area. The very low value of $\mathrm{Na}$ is not important since sodium is not necessary for plant growth. With exception of the $\mathrm{pH}$ value, the study values compare fairly well with those of soils in other locations in the semi-arid zones of East Africa: pH (7.0 - 8.7), N (0.2), SOM (0.5 - 3.0), P (15) and $\mathrm{K}(0.19)$ [18].

The results of CP levels for Pennisetum purpureum (NARO Napier 3), Brachiaria mulato and Pennisetum purpureum (NARO Napier 2) were higher than what was reported of these pasture species in Uganda. For example, a study by Kabirizi et al. [19] reported 9.2\% CP for NARO Napier 3 while NARO Napier 2 had $8.4 \%$. Whereas the values by Kabirizi et al. [19] and those provided by EAAPP [20] in other studies in Uganda (6.4\% - 9.2\%) were generally lower than those of our study, it is not surprising because the $\mathrm{CP} \%$ in the current study was determined by multiplying $\mathrm{N} \%$ by $6.25(\mathrm{CP} \%=\mathrm{N} \% \times 6.25)$ as recommended by 
Moran [12]. If this recommended method is used, calculation of $\mathrm{CP} \%$ is done including the non-protein nitrogen and the value obtained is expected to be relatively higher. Nevertheless, the results were within the range $(7.2 \%-20.4 \%)$ reported by Rusdy [21] and Negawo et al. [22]. Equally, the CP content of Brachiaria mulato was within the range $(9 \%-16 \%)$ reported by the breeder of this hybrid grass variety [23]. Probably, the favourable weather during the study period, fairly fertile soils and the practice of manure application in South-western Uganda could be the plausible explanation for the improved CP content among the improved Napier grass variety samples in our study. The growing of other pasture species such as Rhodes grass (Chloria gayana) and Brachiaria species as observed in the current study is very likely a strategy of pasture species diversification since a significant proportion of the farmers were just starting silage and hay making.

Besides, including Chloris gayana among the pasture species used mainly for "cut and carry" or hay making is not unexpected. Although this grass species could be grazed, it can be cut for hay [24]. Since maize is traditionally the major source of energy in rations in many parts of world, the adoption of maize silage and the use of some additives are encouraging developments.

The practice of late harvesting of Napier grass, as observed in our study, could have affected the quality of the silage since Napier grass leaves (at a later maturation stage) is regarded lignified and hence fibrous [25], with obvious decline in nutritive quality. Specifically, the optimal nutritive value is always expected at about six weeks or any other growth stage not exceeding eight weeks [26]. The practice of late harvesting could have been influenced by knowledge gap since dairy farmers in the sub-region had recently adopted production of maize silage. For the same reason, the small proportion of farmers that grew maize for silage making did not know the right stage at which maize for silage could preferably be harvested. The milk ripe stage at which most of the farmers in this study harvested maize crop for silage could have contributed to poorly fermented silage. At this maturity stage the nutritive value is still low as the cobs have not yet accumulated enough energy content [27]. Regrettably, this was the stage that most livestock extension service providers in Uganda always recommended. Interestingly, some farmers had started harvesting maize for silage at the right stage. Ettle and Schwarz [28] recommend that harvesting of maize should be done when the maize dough is ripe, dark yellow in colour, the grain is still moist and the rest of the content is rather solid. Although most of the farmers did not know how to process maize stalk, some of them cut the stalk to the appropriate theoretical chop length of $1-2.5 \mathrm{~cm}$ that does not hamper silage uptake or milk yield [29] [30]. It was clear that a majority of farms used pit silos for silage preservation, with a few adopting a recent technology of using polythene bags. Regardless of the method used though, silage compaction was poorly done and a significant proportion of silage appeared moldy.

In this study, hay made from star grass in pure stand presented the highest proportion of $\mathrm{CP}$ and mixed naturally growing pastures had the highest level of 
energy. The surprisingly high proportion of $\mathrm{CP}$ is a common finding of star grass among the studied pastures, with some earlier studies showing $\mathrm{CP}$ protein levels of $5.4 \%-22.8 \%$ [31] [32] [33]. Nonetheless, the reason why mixed naturally growing pastures had the highest energy among the study pastures is not clear since lower value $(7.98 \mathrm{MJ} / \mathrm{kg})$ for related mixed grass pastures has previously been reported [34].

Recent literature [19] [34] [35] reports CP of silage of Napier grass as ranging from 7.01\% - 13.9\%. Equally, Mediksa et al. [34], De Oliveira et al. [36] and Wei et al. [37] observed that maize silage had CP in the range of $6.1 \%-9.7 \%$ and $\mathrm{ME}$ of up to $17.6 \mathrm{MJ} / \mathrm{kg}$. Our findings of $13.7 \% \mathrm{CP}$ for Napier grass and $9.38 \% \mathrm{CP}$ for maize and the energy values of 9.80 and $9.60 \mathrm{MJ} / \mathrm{kg}$, respectively, corroborate results in the earlier studies. The fact that the ME of Napier grass and maize was less than $9.9 \mathrm{MJ} / \mathrm{kg}$ demonstrate low energy sources since Lonsdale [38] opined that feeds that have $<9.9-12$ and $>12 \mathrm{MJ} \mathrm{ME} / \mathrm{kg} \mathrm{DM}$ are classified as low, medium and high energy sources, respectively. This could be easily associated with harvesting Napier grass and maize at a wrong stage and poor processing techniques. Nonetheless, the finding that the ME of Napier grass combined with molasses was $10.2 \mathrm{MJ} / \mathrm{kg}$ demonstrate the fact that adding molasses to Napier grass improves the nutritive quality of silage.

The digestibility value for hay of naturally established mixed pastures and that for silage of Napier grass treated with molasses, maize mixed with brewer's spent grain and maize alone were above $60 \%$ and these were the only category of samples with fairly acceptable nutritive value parameters. Pastures can only be considered good quality if digestibility is $60 \%-85 \%$; preferably above $67 \%$ [39]. In contrast it was expected that star grass could have low digestibility since it is always in the range of $41.9 \%-56.0 \%$ whenever compared with other grass pastures [31] [33]. Besides, Napier grass silage CP content was on the lower side of the range $(13.4 \%-16.4 \%)$ contrary to results of an earlier study [40]. This is likely due to poor methods of silage making which could certainly affect the quality of the feed. Based on field observations, it is very probable that the silage produced at the study farms had relatively poor palatability and feed safety. The storage conditions could easily predispose to contamination with fungal mycotoxins and/or bacteria such as Clostridium botulinum, Bacillus cereus, Listeria monocytogenes, Escherichia coli, other Enterobacteriaceae species, and moulds [41]. These undesirable microorganisms must have reduced the nutritional quality of silage and hay. Moreover, yeasts and butyric acid bacteria for instance, are hazardous and detrimental to animal and human health, as they affect milk safety and that of other animal food products.

Existing literature indicates that silage additives cause diverse benefits in nutritive value of silages and in reduction of risks during the ensiling process [42]. Equally, it is reported that treating with molasses improves silage preservation and silage dry matter intake, though it does not significantly alter the silage digestibility or animal performance [43]. Based on this knowledge, most of the farms added molasses and maize bran during ensiling and/or silage feeding, with 
the purpose of increasing palatability and nutritive value. Other farms added livestock microbes such as MolaPlus ${ }^{\circledR}$ with the aim of improving digestibility. For similar reasons, maize bran, molasses, chopped forage legumes and/or mineral lick were added to hay at the time of feeding. Whereas there was diversity of additives used at the processing or feeding stage of silage or hay, there was no observable difference in especially the silage produced using the different additives or as a result of its feeding. Besides, it was not clear which specific microbes were contained in the different additives.

The positive margins observed for both silage and hay feeding suggest that it is profitable for dairy farmers to invest in dry season feeding. Thus, farmers should be encouraged to adopt these technologies. For both silage and hay production, labour costs contributed the highest proportion of total production costs. The challenge of high labour costs is not unique to Uganda; it has been reported in other countries such as Pennsylvania where Ranck et al. [44] found that high cost of production due to high labour expenses affected profitability of making silage. Nevertheless, the cost-benefit analysis shows positive benefit-cost ratios for both silage and hay implying that production and feeding of any of the two feeds is still viable. This is explained by the fact that high costs are compensated by an increase in milk prices during the dry season. Our results corroborate those of previous studies that demonstrated positive economic returns from feeding silage and hay [6] [7]. While we considered only milk production, it is also known that proper feeding of silage and hay improves the body condition score of animals [5]. However, the study did not analyse the parameter of body condition score due to logistic limitations. Besides, the fact that the wet season occurred in most of the study districts throughout the study period interfered with generation of the planned data. Hence, the available data was inadequate for satisfactory statistical analysis.

\section{Conclusion}

The quality of silage and hay produced on study farms was relatively inadequate. While almost all the silage and hay had acceptable level of CP ( $\geq 9.9 \%)$, all silage and hay (not treated with any additive) were of relatively low quality since the ME was less than 9.9 MJ ME/kg DM and ration digestibility was less than $67 \%$ that limit feed intake due to indigestible residue in the digestive tract. According to Hibbs and Conrad [39], green pasture can only be good quality if digestibility $(60 \%-85 \%)$, is higher than senescent (dead) herbage $(35 \%-60 \%)$ of the same species if adequate digestibility is to be achieved. Farmers that grew pastures, preserved and fed silage/hay to lactating cows could nonetheless breakeven. This is because feeding silage/hay of any quality resulted in increase in milk yield among the fed cows compared to those starved due to excessive pasture scarcity experienced during the dry season. The resultant increase in milk production per cow due to feeding silage was higher than that from hay feeding. There is high potential for profitable dairy production in South-western Uganda if more 
farmers adopt hay and silage feeding, more so when recommended pasture preservation methods are used. There is need to sensitize and train farmers on how to improve pasture growing and, silage and hay making and the associated benefits. Equally important is to train farmers in record keeping. Otherwise, further research is needed to understand the effect of silage and hay feeding on parameters such as body condition score and milk quality (butterfat, protein and mineral content).

\section{Acknowledgements}

This work was co-funded by The Inclusive Dairy Enterprise (TIDE) project (Phase-1; 2015-19) implemented by SNV Netherlands Development Organization in Southwest Uganda. The TIDE project is funded by the Embassy of the Kingdom of the Netherlands in Kampala. We acknowledge the technical contributions from Rinus van Klinken, Paul Kimbugwe and Joseph Kiirya. We equally thank the farmers/respondents who provided information during data collection.

\section{Conflicts of Interest}

The authors declare no conflicts of interest regarding the publication of this paper.

\section{References}

[1] FAO (Food and Agriculture Organisation of the United Nations) (2019) The Future of Livestock in Uganda. Opportunities and Challenges in the Face of Uncertainty. Rome.

[2] Mannetje, L. (2000) Introduction to the Conference on Silage Making in the Tropics. Proceedings FAO Electronic Conference on Tropical Silage, 1 September-15 December 1999, 1-4.

[3] Castro-Montoya, J. Gownipuram, R., Mendoza, M., Solano, N., Lopez, F., Dichofer, U. and Corea, E.E. (2019) Effects of Feeding Tropical Forage Legumes on Nutrient Digestibility, Nitrogen Partitioning and Performance of Crossbred Milking Cows. Animal Feed Science and Technology, 247, 32-40. https://doi.org/10.1016/j.anifeedsci.2018.10.017

[4] Pousga, S., Traore, M., Belem, A., Millogo, V. and Nacro, H.B. (2019) Effect of Cowpea Hay Supplementation on Milk Production Performance of Local Crossbred Cattle (Bos indicus X Bos Taurus) in Extensive System. World Journal of Agricultural Research, 7, 14-20.

[5] Creemers, J. and Aranguiz, A.A. (2019) Quick Scan of Uganda's Forage Sub-Sector: Netherlands East African Dairy Partnership (NEADAP). Working Paper.

[6] McCorkle, D.A., Hanselka, D., Bean, B., McCollum, T., Amosson, S., Klose, S. and Walle, M. (2007) The Economic Benefits of Forage Sorghum Silage as an Alternative Crop. A\&M University System, Texas Cooperative Extension, College Station.

[7] Krasniqi, F., Kamberi, M.A., Kastrati, R., Emiri-Sallaku, E. and Tafaj, M. (2018) Investigation on Feeding Level and Milk Production of Holstein Dairy Cows under Farm Conditions in Kosovo. Bulgarian Journal of Agricultural Science, 24, 450-459. 
[8] Tibezinda, M., Wredle, E., Sabiiti, E.N. and Mpairwe, D. (2016) Feed Resource Utilization and Dairy Cattle Productivity in the Agro-Pastoral System of South Western Uganda. African Journal of Agricultural Research, 11, 2957-2967. https://doi.org/10.5897/AJAR2016.10785

[9] Murphy, J. and Riley, I.P. (1962) A Modified Single Solution Method for the Determination of Phosphate in Natural Waters. Analytica Chimica Acta, 27, 31-36. https://doi.org/10.1016/S0003-2670(00)88444-5

[10] Landon, J.R. (1993) Booker Tropical Soil Manual: A Handbook for Soil Survey and Agricultural Land Evaluation in the Tropics and Subtropics. Longman, London and New York.

[11] Okablebo, J.R., Gathua, K.W. and Woomer, P.L. (2002) Laboratory Methods of Soil and Plant Analysis: A Working Manual. 2nd Edition, TSBF-CIAT and SACRED Africa, Nairobi, 128.

[12] Moran, J. (2005) Tropical Dairy Feeding: Feeding Management for Smallholder Dairy Farmers in the Humid Tropics. Landlinks Press, Collingwood, 312. https://doi.org/10.1071/9780643093133

[13] AOAC (Association of Official Agricultural Chemists) (1990) Official Methods of Analysis. 15th Edition, Washington DC.

[14] Dowman, M.G. (1993) Modifications to the Neutral Detergent Cellulase Digestibility Method for the Prediction of the Metabolisable Energy of Compound Feedstuffs Containing Palm Kernel Meal. Journal of the Science of Food and Agriculture, 61, 327-331. https://doi.org/10.1002/jsfa.2740610306

[15] Thomas, P.C., Robertson, S., Chamberlain, D.G., Levingstone, R.M., Garthwaite, P.H., Dewey, P.J.S., Smart, R. and Whyte, C. (1988) Predicting the Metabolizable Energy (ME) Content of Compound Feeds for Ruminants. In: TIaresign, W. and Cole, D.J.A., Eds., Recent Advances in Animal Nutrition, Nottingham University Press, Nottingham, 127. https://doi.org/10.1016/B978-0-407-01165-6.50013-4

[16] Ocaido, M., Muwazi, R.T. and Opuda-Asibo, J. (2009) Financial Analysis of Livestock Production Systems around Lake Mburo National Park, in South Western Uganda. Livestock Research for Rural Development, 21, Article \#70. http://www.lrrd.org/lrrd21/5/ocai21070.htm

[17] Marx, E.S., Hart, J.M. and Stevens, R.G. (1996) Soil Test Interpretation Guide.

[18] Egeru, A., Wasonga, O., Gabiri, G., MacOpiyo, L., Mburu, J. and Majaliwa, J.G.M. (2019) Land Cover and Soil Properties Influence on Forage Quantity in a Semiarid Region in East Africa. Hindawi Applied and Environmental Soil Science, 2019, Article ID: 6874268. https://doi.org/10.1155/2019/6874268

[19] Kabirizi, J., Zziwa, E., Nannyenya-Ntege, W., Mugerwa, S. and Lukwago, G. (2013) Improving Smallholder Dairy Cattle Feed Resource Availability and Animal Productivity. National Livestock Resources Research Institute (NaLIRRI) Eastern African Agricultural Productivity Project (EAAPP). https://www.jollykabirizi.com/images/at-banners/Feed.pdf

[20] EAAPP (Eastern African Agricultural Productivity Project) (2013) Enhancing Adoption of Napier Grass Varieties Tolerant to Stunt Disease for Increased Feed Availability in Smallholder Dairy Systems in East and Central Africa. https://www.jollykabirizi.com/images/at-banners/newsletter.pdf

[21] Rusdy, M. (2016) Elephant Grass as Forage for Ruminant Animals. Livestock Research for Rural Development, 28, Article \#49. http://www.lrrd.org/lrrd28/4/rusd28049.html 
[22] Negawo, A.T., Teshome, A., Kumar, A, Hanson, J. and Jones, C.S. (2017) Opportunities for Napier Grass (Pennisetum purpureum) Improvement Using Molecular Genetics: Review. Agronomy, 7, 28. https://doi.org/10.3390/agronomy7020028

[23] Argel, P.J., Miles, W.J., Guiot, H.C. and Carlos, E.L. (2007) Cultivar Mulato II (Brachiaria Hybrid CIAT 36087): A High Quality Forage Grass, Resistant to Spittlebugs and Adapted to Well Drained, Acid Tropical Soils. http://ciat-library.ciat.cgiar.org/Articulos Ciat/mulato ii ingles.pdf

[24] Cook, B.G., Pengelly, B.C., Brown, S.D., Donnelly, J.L., Eagles, D.A., Franco, M.A., Hanson, J., Mullen, B.F., Partridge, I.J., Peters, M. and Schultze-Kraft, R. (2005) Tropical Forages. CSIRO, DPI\&F (Qld), CIAT and ILRI, Brisbane.

[25] Jagadeesh, C., Reddy, Y.R., Nagalakshmi, D., Mahender, M., Kumari, N.N., Sridhar, K. and Devi, K.B.S. (2017) Effect of Stage of Harvest on the Yield, Chemical Composition, in Vitro and in Sacco Digestibility of Hybrid Napier (Penniserum purpureum) Variety APB N1. Indian Journal of Animal Research, 51, 116-120.

[26] Manyawu, G.J., Sibanda, S., Mutisi, C., Chakoma, I.C. and Ndiweni, P.N.B. (2003) The Effect of Pre-Wilting and Incorporation of Maize Meal on the Fermentation of Bana Grass Silage. Asian-Australasian Journal of Animal Sciences, 16, 843-851. https://doi.org/10.5713/ajas.2003.843

[27] Ashbell, G. and Weinberg, Z.G. (2000) Silage from Tropical Cereals and Forage Crops. FAO Plant Production and Protection Papers, 109-116.

[28] Ettle, T. and Schwarz, F. (2003) Effect of Maize Variety Harvested at Different Maturity Stages on Feeding Value and Performance of Dairy Cows. Animal Research, 52, 337-349. https://doi.org/10.1051/animres:2003023

[29] Preissinger, W., Schwarz, F.J. and Kirchgessner, M. (1998) The Effect of Size Reduction of Corn Silage on Feed Intake, Milk Production and Milk Composition of Cows. Archiv fur Tierernahrung, 51, 327-339. https://doi.org/10.1080/17450399809381930

[30] Bal, M.A., Shaver, R.D., Jirovec, A.G., Shinners, K.J. and Coors, J.G. (2000) Crop Processing and Chop Length of Corn Silage: Effects on Intake, Digestion, and Milk Production by Dairy Cows. Journal of Dairy Science, 83, 1264-1273. https://doi.org/10.3168/jds.S0022-0302(00)74993-9

[31] Antwi, M.K. (1977) Seasonal Variation in Chemical Composition and Dry Matter Digestibility of Digitaria decumbens and Cynodon dactylon in Admixtures with Desmodium intortum. Ghana Journal of Agricultural Science, 10, 117-120.

[32] Prins, H.H.T. (1996) Ecology and Behaviour of the African Buffalo: Social Inequality and Decision-Making. Wildlife Ecology and Behaviour, Series, No. 1, Chapman \& Hall, London.

[33] Ramchurn, R., Dullull, Z.B., Ruggoo, A. and Raggoo, J. (2000) Effects of Feeding Star Grass (Cynodon plectostachyus) on Growth and Digestibility of Nutrients in the Domestic Rabbit. Livestock Research for Rural Development, 12, 31-37. http://www.cipav.org.co/lrrd/lrrd12/2/ram122.htm

[34] Mediksa, T., Urgie, M. and Animut, G. (2016) Effects of Different Proportions of Pennisetum Purpureum Silage and Natural Grass Hay on Feed Utilization, Milk Yield and Composition of Crossbred Dairy Cows Supplemented with Concentrate Diet. Journal of Biology, Agriculture and Healthcare, 6, 59-71. http://www.iiste.org

[35] Ofori, A.D. and Nartey, M.A. (2018) Nutritive Value of Napier Grass Ensiled Using Molasses as an Additive. The International Journal of Engineering and Science, 7, 45-50. 
[36] De Oliveira, I.L., Lima, L.M., Casagrande, D.R., Lara, M.A.S. and Bernardes, T.F. (2017) Nutritive Value of Corn Silage from Intensive Dairy Farms in Brazil. Revista Brasileira de Zootecnia, 46, 494-501. https://doi.org/10.1590/s1806-92902017000600004

[37] Wei, Ming, Chen, Z., Wei, S., Geng, G. and Yan, P. (2018) Comparison among Methods of Effective Energy Evaluation of Corn Silage for Beef Cattle, Asian-Australasian Journal of Animal Sciences, 31, 851-858. https://doi.org/10.5713/ajas.17.0538

[38] Lonsdale, C. (1989) Raw Materials for Animal Feeds Compounders and Farmers. Chalcombe Publications, Marlow, 17-47.

[39] Hibbs, J.W. and Conrad, H.R. (1978) Minimum Concentrate Feeding for Efficient Milk Production. World Animal Review. http://www.fao.org/3/X6512E24.htm

[40] Widiyastuti, T., Hidayat, N. and Indrasanti, D. (2014) Nutrient Content of Napier Grass (Pennisetum purpureum) Silage Made with Various Additive and Modified Atmosphere in the Silo. Animal Production, 16, 11-17.

[41] Driehuis, F., Wilkinson, J.M., Jiang, Y., Ogunade, I. and Adesogan, A.T. (2017) Silage Review: Animal and Human Health Risks from Silage. Journal of Dairy Science, 101, 4093-4110. https://doi.org/10.3168/jds.2017-13836

[42] Yitbarek, M.B. and Tamir, B. (2014) Silage Additives: Review. Open Journal of Applied Sciences, 4, 258-274. https://doi.org/10.4236/ojapps.2014.45026

[43] Keady, T.W.J. (1996) A Review of the Effects of Molasses Treatment of Unwilted Grass at Ensiling on Silage Fermentation, Digestibility and Intake, and on Animal Performance. Irish Journal of Agricultural and Food Research, 35, 141.

[44] Ranck, E.J., Holden, L.A. and Soder, K.J. (2019) Evaluating Feed Cost, Income over Feed Cost, and the Cost of Production for Milk and Crops on 4 Case Study Farms That Double Cropped Winter Annual Silage and Corn Silage for 2 Years in Northern and Western Pennsylvania. Applied Animal Science, 35, 74-82.

https://doi.org/10.15232/aas.2018-01792 